\title{
Academic Writing at Graduate School: An Attempt at Its Demystification
}

\author{
Angela Yicely Castro Garcés ${ }^{1, *}$ \\ ${ }^{1}$ English and Spanish Department, Universidad del Tolima, Ibagué, Colombia \\ *Correspondence: Faculty of Education, English and Spanish Department, Universidad del Tolima, Ibagué, \\ Colombia. E-mail: aycastrog@ut.edu.co
}

Received: March 4, 2016

Accepted: March 11, 2016 Online Published: March 20, 2016

doi:10.5430/wjel.v6n1p25

URL: http://dx.doi.org/10.5430/wjel.v6n1p25

\begin{abstract}
This article reports the findings of a qualitative research study carried out in an academic writing class, with English Didactics Master's students. It aims at identifying graduate students' pre-conceptions of academic writing, describing the process undertaken in an attempt to demystify academic writing, and empower students to write and publish. Data collection instruments included an initial and a final survey, a student journal, and a series of templates for the building of arguments. The findings suggest that recognizing students' potential and providing them with the necessary tools to improve their writing process are key factors in fostering more confident, better writers and the beginning of the writing demystification process.
\end{abstract}

Keywords: academic writing; demystification; graduate students; pre-conceptions

\section{Introduction}

Overcoming the blank page barrier is the first challenge novice writers need to face before they are able to start putting their ideas together. As teachers, persuading students to write and accompanying them along their writing journey is a challenge present at any educational level. Granted that writing is sharing, expanding our thoughts and putting them in written form to be accessed by a specific audience, Graff and Birkenstein (2006) state that "writing is entering a conversation with others, not only expressing our own ideas, but doing so in response to what others have said" (p. IX). Giving students the necessary elements to build confidence and move from writing for assignments to writing for pleasure, once they learn to value themselves as writers, is one of the goals teachers are to reach in a writing course. Therefore, as this is not an easy task, it is necessary to design a writing course tailored to students' needs and interests. In this regard, hereafter I describe the three main components of a writing course taught to graduate students in an English Didactics Master's Program. First, knowing their pre-conceptions about academic writing was the starting point to understand them as individuals who might have been afraid of facing the blank page barrier. Second, working on awareness-raising activities that included presentations of what other people are writing in our field, using academic journals, and emphasizing the need and possibilities of writing and getting published was the next relevant step in beginning to demystify academic writing. Third, giving students the opportunity to identify and familiarize themselves with different kinds of texts, from book reviews to articles, allowed them to realize that academic writing can be democratized and not necessarily fitted into a unique format.

The data collection instruments helped analyze students' pre-conceptions in order to consider their previous writing experiences. The building of arguments was encouraged as part of academic writing, based on the book They say, $I$ say: The moves that matter in academic writing (Graff \& Birkenstein, 2006). Students were also able to see academic writing closer to them as they explored the many opportunities they had to approach this field. As a result, students acknowledge that the learning derived from this course gave them valuable tools to continue writing on their own, feeling that academic writing and publishing is closer to their reality than they previously thought.

\section{Literature Review}

The two theoretical constructs supporting this research study are academic writing and writing demystification. 
Following is a summary of relevant work done in this specific area.

\subsection{Academic Writing}

In his seminal book 'La Cocina de la Escritura, Cassany (1995) advises that there are no magic recipes for writing. He acknowledges the importance of reading for writing and presents a Decalogue for writing, as he warns that novice writers cannot become seasoned writers overnight, since writing well takes time, passion and patience. He further warns that writing is "being able to express information in a coherent and correct way to be understood by others(Note 1)" (p. 13). Knowing that writing is not an easy task, he compares this process to the building of a house, noting that it requires the skill of elaborating different kinds of texts, including letters, complain notes, abstracts, reports, and much more. Academic writing (AR), as defined by Green (2013), is "a complex socio-cognitive process encompassing a range of textual and interpersonal interactions" (p. 180).

Green carried out a study about the situated academic writing processes of three novice ESL writers in a TESOL context. This study offers insights into the approaches novice writers use to complete academic assignments and the connections between approach and writing quality, particularly with regard to textual or interpersonal interactions that generate meta-knowledge related to writing. Furthermore, a series of publications on academic writing, including (Hacker, 2003; Jordan \& Plakans, 2003; Lilis \& Curry, 2010; Oshima \& Hogue, 2006; Swales \& Feak, 2012) help students develop the writing skills needed to succeed at college and graduate school, instructing them on topics such as rhetorical elements, principles and patterns for college-level essays, academic genres, summary and critiques writing, and the process of reflecting, reacting, and revising. Swales and Feak (2012) provide specific guidelines on the writing of academic texts, including tasks to practice structural, stylistic and rhetorical issues, data commentary and research papers. They invite students to see academic writing as a product of taking into consideration key elements as audience, purpose, organization style, flow and presentation. Additionally, in Academic Writing in a Global Context, Lillis and Curry (2010) acknowledge the advantages of academic writing as a collaboratively, social activity. In her book A Writer's Reference, Hacker (2003) establishes a guide for revising and editing a draft, a book that as she indicates "lies flat, making it easy to consult..." (p. v).

Other works published in the area, in the form of research articles include Torrance, Thomas and Robinson's (1994), which reports on the strategies used by graduate students when composing, and identifies three broad approaches in which writers invested as much time in planning as in drafting. In a subsequent publication, Torrance, Thomas and Robinson (2000) present a large-scale, longitudinal study in which they identify four approaches writers undertook: (a) 'detailed-planning' - outlining and brainstorming or mind mapping before drafting; (b) 'outline-and-develop' pre-draft planning and initial content development; (c) 'minimal-drafting' -writers wrote one ort wo drafts with little prior planning; and (d) 'think-then-do'- mental planning without a written outline. This study sheds light on individual differences among writers. Likewise, in the Colombian context, Chala Bejarano and Chapeton (2013) think of writing as a situated social practice. They carried out a research study that "emerged from the necessity to foster transformation in writing practices, which privileged a product over a process view of writing and allowed opportunities for students to express their voices in a meaningful way" (p. 128). Their study is in line with the analysis reported in this present work, as it values students as individuals and considers the process that leads them to be better writers and echoes Castro (2012) claim that "having learners understand and reflect upon their own learning process is essential for successful long-term learning to take place" (p. 127).

\subsection{Writing Demystification}

It is commonplace that students see writing as a complex activity or a task done in response to others, but not necessarily as an activity that makes part of their learning process, or as contribution to their professional development once they graduate. Thus, presenting students with the possibilities they have for writing and giving them the necessary tools to succeed in writing effectively is essential. In this respect, demystifying can be thought of as making academic writing more plain and less mysterious, which is coupled with democratizing, or making writing available to everyone. These two concepts are necessary elements for students to approach writing as a learner-friendly activity. Graff and Birkenstein (2006) present a model that helps students demystify academic writing by simplifying key basic moves and by teaching them how to enter a conversation with others. It is true that models should not be taken as recipes to follow blindly, but instructors can use them as personalized guides. Besides, given the idiosyncratic nature of a writer's experience and of writing itself, it is likely that not all writers succeed by following the same path. Accordingly, Driscoll and Aquilina (2011) contend that one of the greatest skills in writing is to keep it simple. They present a practical six-step approach to writing for publication and encourage new authors to do so by taking reading, selecting an appropriate journal, and planning and structuring their work as preparation for writing. 
Additionally, Hartley (2008) presents a guide for writing and publishing that helps novice as well as seasoned writers reflect upon this process while considering the different alternatives they have to succeed. He asserts that "academic writing does not take place in a social vacuum and the motives for writing are mixed and various. Today's academics are expected to produce papers, which affects what is researched, who does it, who writes it up, where it is published, and so on " (p. 14). He also acknowledges that individual writers have distinct styles and voices. These differences in styles and the reasons for writing are to be considered when teaching a writing class, at any level, since valuing students' needs makes writing more pleasant, which may eventually result in better writing products. Moreover, Lillis and Curry (2010) point out the need for scholars to have their voices heard in a global context; in this regard, they acknowledge the central role English plays in the globalizing systems and practices, given the fact that it has grown as the global medium of academic publications.

On the other hand, Canagarajah (1996) asserts that academic discourse is culture bound and reflects on the real possibilities that periphery scholars have for writing and publishing in the broader community, as he argues that the requirements of academic publishing can serve exclusionary functions. She also gives possibilities to ensure a better exchange of knowledge, which can be taken as an invitation to continue considering the need to involve our students in the writing of texts, the creation of arguments and the publication of papers from an earlier stage in their careers.

\section{Method}

This study presents a qualitative analysis of the pre-conceptions graduate students have of writing and the likelihood of demystifying academic writing.

\subsection{Participants}

This research was conducted at a State University in Colombia. The population was made up of a group of twelve English teachers enrolled in the first semester of the Master in English Didactics. They took four seminars during the first semester: Introduction to Foreign Language Didactics; Policies, Discourse and Contexts; Research Foundations in Foreign Language Didactics; and Academic Writing. The last one of these seminars, from which this study originated, was designed to provide students with tools that enable them to find, evaluate, and respond to relevant literature related to the Didactics of English, write different kinds of academic texts following the writing process, and encourage them to write and publish their own work. This comprised 36 hours of classroom instruction and 108 hours of student independent work, for a total of 144 hours. Out of the twelve participants, seven are high school teachers and five are University and Language Institute teachers. Their teaching experience ranges from 1 to 12 years and their English proficiency level goes from B2 to $\mathrm{C} 1$ in the Common European Framework of Reference for Languages. Along their teaching career, they have written different kinds of texts but none of them has published his work. Therefore, this course is relevant in their educational process.

\subsection{Data Collection Process}

In order to identify graduate students' pre-conceptions and describe the processes undertaken to attempt the demystification of academic writing, the following instruments were used to collect data: An initial and a final survey, a student journal, and a series of templates for the building of arguments. The initial survey had five questions that explored students' previous writing experience, the relevance they gave to this process, and the expectations they had of an academic writing course. The journal had three entries in which students had the chance to write about their strengths, challenges, learning experiences, and personal reflection at the end of three of the six sessions studied. The building of arguments was encouraged and facilitated through a series of templates taken from Graff and Birkenstein (2006) in order to help students react, compare and contrast their own words to the words of others. The purpose of using templates was not to hinder students' critical thinking nor to encourage passive learning, which would go against the social and creative nature of writing, but to "be direct with students about the key rhetorical moves that comprise writing" (Graff \& Birkenstein, 2006). The final survey had three questions that were intended to describe the process students experienced in their academic writing course, find out how templates had helped the building of arguments and what fears students still had, regarding academic writing.

All the activities carried out along this course aimed at helping students reach course objectives and gain knowledge not only for completing class assignments but also for their future career as teachers, researchers, and writers.

\section{Results and Discussion}

The instruments administered allowed me to identify graduate students' pre-conceptions of academic writing and to 
explore the likelihood for demystifying academic writing in this group of graduate students. Following is the analysis of the initial survey, the presentation of key reflections written in the journals, an interpretation of the use of templates for the building of arguments, and a synthesis of the answers given to the final survey.

Table 1 presents a summary of the answers given to the initial survey, which served as needs analysis for this seminar and would help open the discussion on students' pre-conceptions and expectations of this academic writing course.

Table 1. Initial Survey

\begin{tabular}{|c|c|c|}
\hline 1 & How often do you write? & $\begin{array}{l}\text { From time to time just describing situations at school } \\
\text { Only when I am studying } \\
\text { When my job requires it } \\
\text { Almost every day because of my job } \\
\text { Sometimes when I need it } \\
\text { Seldom because I haven't felt forced to do it } \\
\text { Not as much as I would like, only what my job requires } \\
\text { Two or three times a week, but not with academic purposes } \\
\text { All the time because I like it }\end{array}$ \\
\hline 2 & $\begin{array}{l}\text { What kind of texts have you } \\
\text { written? }\end{array}$ & $\begin{array}{l}\text { Short stories, letters, personal reflections, descriptive, argumentative } \\
\text { and narrative texts }\end{array}$ \\
\hline 3 & Who do you write for? & $\begin{array}{l}\text { For myself, for teachers, for pleasure, for my friends, for school, for } \\
\text { my students }\end{array}$ \\
\hline 4 & $\begin{array}{l}\text { How important is an academic } \\
\text { writing course at graduate } \\
\text { level? }\end{array}$ & $\begin{array}{l}\text { Important to learn to express our ideas in an academic way } \\
\text { Great to put ideas on paper } \\
\text { Writing is difficult, then a course is important to do research } \\
\text { Essential for my academic life } \\
\text { Significant } \\
\text { Useful to organize my thoughts in a better way } \\
\text { Good to document my ideas } \\
\text { It is the base for research class } \\
\text { It is necessary to develop academic writing }\end{array}$ \\
\hline 5 & $\begin{array}{l}\text { What do you expect to gain } \\
\text { from this course? }\end{array}$ & $\begin{array}{l}\text { To learn for myself and for my students } \\
\text { To improve my writing skill } \\
\text { To analyze and produce academic texts } \\
\text { To learn to organize my ideas in a better way } \\
\text { To gain vocabulary and improve grammar } \\
\text { To Learn how to write professionally }\end{array}$ \\
\hline
\end{tabular}

Question 1 refers to the time students spend writing, which shows that they write in response to a task or as part of their job requirements. There were just two students who mentioned writing for pleasure, which unveils the need for presenting writing as a pleasurable activity they can be involved in with different purposes. Questions 2 and 3 show that students write a variety of texts for different audiences; although their bosses, colleagues and students are the main audience; there are some who write for friends, finding pleasure in the process. Finally, questions 4 and 5 present academic writing at graduate school, to start situating students in the academic context. The answers to these questions show the need students have for gaining tools for writing academically, in order to improve their writing skills, help their own students write better, and produce academic texts. This initial survey presents a context in which teachers have a need for improvement. Contrary to what I had expected, none of participants referred to academic writing as being a subject they did not want to study or were not interested in.

\subsection{Journal}

Students' journal entries present their strengths, challenges, learning and personal reflections along three academic writing sessions as an essential tool for them to see themselves as teachers-learners. Borg (2009) states that teacher cognition is understanding what teachers think, know and believe, and what concerns they have about the unobservable dimension of teaching - teachers' mental lives. He believes that what teachers do is directed in no small 
measure by what they think.

Following is a synthesis of what the participants mentioned as the most remarkable moments during three sessions.

Table 2. Journal

\section{Strengths}

I am open-minded to learning

I have certain ability to write in English, but need more practice

I feel comfortable writing in English

I did a good job today. I could link my ideas together

I was able to write my bio-data coherently

I have gained more confidence

I am good at developing general ideas

I participate actively and like to share my knowledge

I am good at following guidelines

Being receptive is my major strength

My motivation and determination

Inspiration and responsibility

I am responsible and like reading and studying

\section{Challenges}

I need to have more content knowledge

To expand my vocabulary

Reading more to have more evidence

To know more about theories

I want to start publishing

I want to do research and write

Time is my biggest challenge

Graduate school is demanding

Need to gain confidence

Writing a good essay demands time for research

Learning how to do in-text citation and write a reference page

I want to participate in class more actively next time

Writing a cover letter was difficult for me

Writing is not only sitting and writing, there is much more to it

Structuring a text

Punctuation

Transition signals

To study hard in order to achieve my goals

\section{Learning}

The guidelines learned for writing help me to be more concrete

The use of databases and resources at the library

I have discovered new ways and conceptions about teaching

Now I can do a better job with in-text citations and reference pages 
Writing for specific purposes (bio-data, cover letter)

Planning, drafting and revising

Rhetorical modes in academic writing

Identifying and writing a main idea, topic sentence and concluding sentence

To connect my ideas with other author's ideas without plagiarizing

Templates were useful for quoting and making transitions

I have learned new strategies for writing and also remembered some other

I learned to reflect on my own writing and to learn from my peers as well

\section{Personal reflection}

I like evaluating what I am doing everyday

I always question my practices

I have to work hard to achieve my objectives

I need discipline, motivation and creativity to face new challenges

The more you write, the better you get

I can do it, I can get the best out of this Master's

It is necessary to do research and write academic papers

The teacher's feedback has encouraged me because now I make few mistakes

I thought I was good at writing, but now I know there is still a lot to learn

I am glad I took the challenge of continuing my education; I have learned a lot

I don't want to be a passive teacher. I want to innovate

I can give more of myself than I thought I could

Writing is not simple, but learning how to do it is wonderful

It is important to improve our writing for our jobs

I have to read if I want to improve my writing

I need to change my negative opinion about writing

Now I am considering the possibility of writing and publishing

I think we need to start writing and we will find this to be an enjoyable activity

Analyzing students' thoughts behind writing, knowing what they have experienced during a lesson and their fears and growth, is an essential constituent for teachers to understand what students have in mind as to set up strategies to help them get the best out of any learning process. Borg (2003) asserts that although professional preparation does shape trainees' cognitions, programs which ignore trainee teachers' prior beliefs may be less effective at influencing them. The table above exemplifies students' perceptions of themselves, and unveils their thoughts and believes about a subject matter which might in the end influence their learning process.

All participants acknowledge that the course has helped them in the process of becoming better writers. Even more, some students' ideas of writing have changed for the good as they now see they are good at writing. However, for a few of them, following guidelines and writing more professionally represents a big challenge. They acknowledge having had the chance to refresh their knowledge, going back to books, reading, writing, recalling strategies they use for writing and learning new strategies which will help them go on by themselves, once they finish this seminar. Giving students the opportunity to think of their strengths allows them to value themselves as writers, which may change some of the pre-conceptions they brought to the course.

\subsection{Templates}

Since many novice writers find it difficult to connect their ideas to those from other authors in order to build arguments, the use of templates was integrated in this seminar in order to help students find a balance and make connections at the time of writing, based on the premises of the authors they had read. 
One of the texts students read and reacted to was 'Language and Symbolic Power', by Bourdieu (1991). Most participants were able to enter into conversation with the text at the time of writing. Transitions present in the templates helped their writing's flow and voice as writers heard over Bourdieu's voice. As a result, there was a good balance between what they read, the thoughts provoked by the writer and what they finally wrote in the reaction papers. In this regard, using Graff and Birkenstein's templates is not done with the purpose of framing students within a certain model which deprives them of the possibilities to think beyond. Instead, it encourages them to use a set of fixed expressions that will nourish their writing and make them become more seasoned writers. Following are some expressions that include transitions the participants used in their reactions, based on the templates provided:

Table 3. Templates

...the communicative use of language is now advancing with Bourdieu's ideas which I totally agree with.

Linguistic exchange, Bourdieu argues, is also an economic exchange...

I have always believed that the Colombian political leaders...

My own view is similar to Bourdieu's when he takes the old model of communication...

Getting back to my point, my whole life...

Need notwithstanding, the powerful country leader...

I support this view with what Bourdieu claims as a strategy of...

I wholeheartedly endorse with Bourdieu's comparison of any linguistic exchange with...

First of all, this topic is completely new for me...

Moreover, I consider...

Bourdieu declares that language is rarely a pure instrument of communication...

One of the implications of Bourdieu's model which I mostly disagree with is...

Basically what I consider here is that Bourdieu's argument...

By highlighting these concepts I wanted to point out that although these symbolic relations...

One controversial issue is the way he develops this topic...

My own view is that the linguistic production is...

Clearly, taking everything into consideration, linguistic exchanges are...

...that's what Bourdieu calls a symbolic power underlying...

...no one denies that the essential purpose of language is... however, the curriculum insists on...

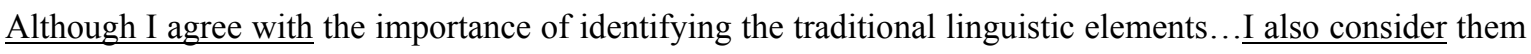

to be outdated for...

In these pages, I will try to show...

Pierre Bourdieu proposes an economic dynamic...

...I agree with that because...

Students' ability to play with templates demonstrates their understanding of such templates as a model, not necessarily a frame. Even if students were encouraged to use the model in order to have a more varied language in their writings, they were also given freedom to decide which ones to use and how to incorporate them in their texts. It was pleasant to read their reactions as most of them demonstrated good language use and great sense of reflection and critical thinking. Nonetheless, it was difficult for a few students to include new transitions and new ways to approach a text as they kept repeating the same expressions they were already familiar with.

\subsection{Final survey}

The three questions included in the final survey aimed at having students reflect upon what had been done along the seminar. Having a final survey helps students reflect upon the process they lived and value the new tools they have gained for their professional lives, including the gaining of self-assurance, an essential factor in becoming better writers. 
Table 4. Final Survey

1 Did this course help you demystify academic writing?

If so, to what extent?
Yes, now I see writing as a continuous process that demands practice.

Yes, I can organize my ideas better and I know that practicing and applying the techniques learned in this course will help me improve.

Yes, this course has given me the opportunity to read and write, and most importantly to avoid the idea that I am not able to.

This course has given me the idea that I am not so bad at writing, but I need to spend more time in the process of planning, writing and revising.

Yes, I overcame fears and realized it wasn't such a strange thing to do. I have been improving constantly.

Yes, writing wasn't a habit for me, but surprisingly I have a new beginning when my writing started to flow and the 'techniques' I used really worked.

At the beginning I was happy with the idea of writing academically and of mixing it with reading and my own experience. Now I want to continue the process of writing articles and publishing.

Yes, I had many doubts but this class has encouraged me to write and share what I write.

Yes, I enjoyed the process lived to such extent that I want to keep on writing. Yes, at first I thought that I didn't have ideas, but using the strategies I can do a better job now.

Yes, I think writing empowers me

Yes, I have discovered the writer inside me; I want to continue writing and learning more every day.

Although I have considered writing as a complex and demanding process, now I know that following guidelines and reading are essential elements for writing.
2 What remaining fears do you have when writing?

\section{I still find it \\ of view.}

No fears, but the writing process is a challenge.

Lack of coherence

Writing my own ideas in an academic text.

That my ideas are not meaningful

Not to be able to write clearly as to be understood by others.

Not to use the correct structure.

I need to use more synonyms so I don't overuse words.

I need to develop my own writing style

Lack of time to be a good writer

I still make many grammar mistakes

3 Did templates help you build and develop arguments when writing? Please explain.
Yes, they provide useful information to make our writing more interesting and significant.

Yes, some were difficult for me to understand, but I need to practice more.

Yes, but not only templates, but all the material and elements provided in this course. Yes, I didn't know anything about them, but when I used them they gave me a lot of possibilities to have my write and connect to the work of others.

Yes, they make my text more sophisticated. I will continue using them.

Yes, especially when trying to establish the tone at the time to write.

Yes, they helped me to organize my thoughts in order to write better.

Yes, they helped me say things in a more formal way. They helped me develop my arguments more deeply.

Yes, they helped me develop my ideas in the way I really wanted to do it.

Yes, but I still need to practice more using them because they sometimes become confusing.

Yes, I didn't use to write formally or use argumentative language, but using templates helped me use supporting phrases that demonstrate my argumentative purpose. I use more varied language now. 
Encouraging students to take mystery out of the writing process is the beginning step in empowering them to see the writer in themselves. No one said it was an easy task, but in the process, students were able to set goals for themselves and find academic writing at their reach, as long as they dedicate the time needed to work toward expected outcomes. Yet, and even if many fears have been overcome, there are other ones students will have to deal with. One significant implication of this process is that students can do an introspection of themselves as writers and get to know that making mistakes, facing new challenges and working on their own is part of the process of becoming better writers. Additionally, the answers given to question three appear to point out that the use of templates slightly helped students build arguments, but more strongly facilitated the development of argumentative ideas they already had. Templates allowed students to expand their vocabulary and find the appropriate expressions to help their writing flow more smoothly.

\section{Conclusions}

Making an attempt to start demystifying academic writing seems to be a good strategy in empowering graduate students in the process of becoming better writers, while considering an audience, other than their teacher, to share their writings with. The findings appear to point out that recognizing students' potential and providing them with the necessary tools for improving their academic writing process are key elements in the building of strong and confident writers.

This study allowed me to identify some of the pre-conceptions graduate students have about academic writing and depicted the likelihood to demystify academic writing as follows:

First, students acknowledged the importance that producing academic texts has for their professional life. Second, they recognized and expressed the strengths they possess and the learning they gained in a short period of time. This means that they can achieve the goals they set for themselves, if they work hard and dedicate time to write. Third, the different writing pieces they developed, including cover letter, curriculum vitae, bio-data, abstract, literature review, reading reaction, book note, article, and the use of templates for developing argumentative texts allowed them to use the strategies learned and provided them with experience to continue facing new challenges in writing. In the end, they feel that this course, indeed, helped them start demystifying academic writing because they could unveil their strengths and now have the tools needed to continue improving. Needless to say, these students still have a long path to walk in this area, which can be joyfully travelled with the knowledge gained so far, with determination, and the genuine desire to grow as writers.

\section{References}

Borg, S. (2003). Teacher cognition in language teaching: A review of research on what language teachers think, know, believe and do. Language teaching, 36 (2), 81-109. http://dx.doi.org/10.1017/S0261444803001903

Borg, S. (2009). Introducing language teacher cognition. Retrieved from http://www.education.leeds.ac.uk/research/files/145.pdf

Canagarajah, A. (1996). "Nondiscursive" requirements in academic publishing, material resources of periphery scholars and the politics of knowledge productions. Written Communication, 4(13), 435-472. http://dx.doi.org/10.1177/0741088396013004001

Cassany, D. (1995). La Cocina de la Escritura. Barcelona: Editorial Anagrama.

Castro, A. (2012). Pre-service English teachers' strengths and challenges when reading and writing. Perspectivas Educativas, 5, 123-142.

Chala Bejarano, P., \& Chapeton, C. (2013). The role of genre-based activities in the writing of argumentative essays in EFL. PROFILE Issues in Teachers' Professional Development, 15(2), 127-147.

Driscoll, J., \& Aquilina, R. (2011). Writing for publication: A practical Six Step Approach. International Journal of Orthopedic and Trauma Nursing, 15, 41-48. http://dx.doi.org/10.1016/j.ijotn.2010.05.001

Graff, G., \& Birkenstein, C. (2006). They say, I say: The moves that matter in academic writing. New York: Norton \& Company, Inc.

Green, S. (2013). Novice ESL writers: A longitudinal case-study of the situated academic writing processes of three undergraduates in a TESOL context. Journal of English for Academic Purposes, 12, 180-191. http://dx.doi.org/10.1016/j.jeap.2013.04.001 
Hacker, D. (2003). A writer's reference ( $5^{\text {th }}$ ed.). Boston: Bedford/St.Martin's.

Hartley, J. (2008). Academic writing and publishing: A practical handbook. New York: Routledge.

Jordan, M., \& Plakans, L. (2003). Reading and writing for academic success. Ann Arbor: University of Michigan Press.

Lillis, T., \& Curry, M. (2010). Academic writing in a global context: the politics and practices of publishing in English. New York: Routledge.

Oshima, A., \& Hogue, A. (2006). Writing academic English (4 ${ }^{\text {th }}$ ed.). New Jersey: Pearson Longman.

Swales, J., \& Feak, C. (2012). Academic writing for graduate students ( ${ }^{\text {rd }}$ ed.). Ann Arbor: University of Michigan Press.

Torrance, M., Thomas, G., \& Robinson, E. (1994). The writing strategies of graduate research students in the social sciences. Higher Education, 27(3), 379-392. http://dx.doi.org/10.1007/BF03179901

Torrance, M., Thomas, G., \& Robinson, E. (2000). Individual differences in undergraduate essay-writing strategies: a longitudinal study. Higher Education, 39(2), 181-200. http://dx.doi.org/10.1023/A:1003990432398

\section{Note}

Note 1. Original language: Spanish - Translation made for publication purposes 